\title{
FOREWORD
}

\section{PATRIZIA BETTELLA}

\section{PINOCCHIO AND CHILDREN LITERATURE}

With the world-wide celebrations for the one hundred and twentieth anniversary of Carlo Collodi's Le avventure di Pinocchio just behind us and with the new or revived attention in recent years to minority literature and cultural studies, it is very appropriate to devote a special issue of Quaderni d'italianistica to Pinocchio. ${ }^{1}$ The articles presented here testify not only to the ever-growing interest in and to the generativity of Collodi's masterpiece, but also to the scholarly commitment of bringing Pinocchio and children's literature from the traditional sphere of literary analysis into the domain of cultural studies. Expressions of 'low culture' such as television, film, Reality TV shows and Hollywood cinema are traditionally viewed with suspicion by intellectuals and excluded from academic scholarship, while children's literature is often confined to the specialized area of minority literature. In recent years however, even among Italian scholars, more emphasis has been placed on the significance of a broad-ranging concept of culture, on the need to transcend rigid distinction between 'high' and 'low culture' and give serious consideration to various aspects of cultural practice such as children's literature, film, television and Reality TV. By viewing such instances of popular culture as an expression of social, political and power relations, the articles in this issue contribute to the cultur-

${ }^{1}$ In 2003 the anniversary of Le avventure di Pinocchio was honoured in North America with scholarly sessions at conferences in both Canada and the United States. In fact, some of the articles in this issue (Bettella's, Anselmi's, and Hogan's) were first presented during a special session on Pinocchio and children's literature at the congress of the Canadian Society for Italian Studies held, that year, in Halifax. For bibliographical reference on Collodi and Pinocchio see Bruno Traversetti Introduzione a Collodi. The Fondazione Nazionale "Carlo Collodi," established in 1960, continues to publish collections of essays on Collodi and Pinocchio and also hosts a website (www.pinocchio.it) which includes a library with an online catalogue open to the general public for consultation. 
al studies discourse and offer a wider perspective in the field of Italian Studies. ${ }^{2}$

Collodi's Avventure di Pinocchio was serialized in the children magazine Giornale per $i$ bambini between 1881 and January 1883 first as Storia di un burattino and later with the title Le avventure di Pinocchio. ${ }^{3}$ The story of a piece of wood carved by a carpenter into a boy-puppet, whose nose grows when he tells lies, who rebels against adult authority and who, through various adventures and misdeeds, grows to become a real and good boy is familiar to all of us. Collodi's book is considered a masterpiece in children's literature, but also a text which challenges the conventions of the fairy-tale genre. Nicholas Perella, American translator of Pinocchio, defines it as the anti-Cinderella, a parody of the rag-to-riches-tale where, unlike in traditional fables, the only valid rule is the one "God helps those who help themselves" $(17,9)$. Italian scholars have come to revere the Avventure di Pinocchio as one of the best novels in Italian Ottocento narrative and many view it as the book which best expresses the Italian character. Giuseppe Prezzolini considered Collodi's masterpiece a "pietra d'assaggio degli stranieri," a text capable of embodying the essence of Italianness and of the Italian national character. ${ }^{4}$ Renato Bertacchini, Italy's major scholar of Collodi's Pinocchio, shows that most Italian writers and intellectuals in the past decades have come to terms with this text in order to understand whether the formula of Italian national identity really derives from the general perception of Italy as a country of puppets, a nation and a people raised through misfortune and suffering similar to those of Pinocchio. In the century since its publication, Collodi's book has been acknowledged as a classic which can touch individual imagination and be fully appreciated

${ }^{2}$ For the debate about Cultural Studies and Italian scholars see Forgacs and Lumley's "Introduction: Approaches to Culture in Italy", Barański's "Introducing Modern Italian Culture" and Robert Dombroski's "Foreword" to the issue of Annali d'italianistica devoted to Italian Cultural Studies.

3 For the vicissitudes of the story of the puppet in the serialized children magazine from Storia di un burattino to Le avventure di Pinocchio see Traversetti's chapter 5.

${ }^{4}$ Despite Benedetto Croce's elitist approach towards Italian literature, it was thanks to him that Pinocchio entered the Italian literary canon. In his essays on La letteratura della Nuova Italia Croce called this book "il più bel libro della letteratura infantile italiana" and observed that "il legno in cui è tagliato Pinocchio è l'umanità" $(330,331)$. Prezzolini's remarks are quoted in Nicholas J. Perella's "An Essay on Pinocchio," p. 2. For the critical debate on Collodi's masterpiece see Bruno Traversetti's section "Il dibattito critico" in Introduzione a Collodi, pp. 129-136. 
in every culture. If Collodi's masterpiece has generated endless revisitations, adaptations, interpretations, sequels, and even multi-media digital installations, Pinocchio the character has gained such a large mass appeal that it has become a universal cultural icon. ${ }^{5}$

Pinocchio the text transcends both the genre of children literature and the discourse of national identity. As its translation in virtually all known languages proves, its appeal extends beyond the geographical boundaries of the Italian peninsula. The abundance and variety of interpretations and readings is staggering. From Gerard Genot's structuralist reading, to Emilio Servadio's psychoanalytic, to Elémire Zolla's mythopoetic interpretation up to Cardinal Giacomo Biffi's theological christological reading, Collodi's puppet has been compared with heroes and anti-heroes of the great epics of the Western tradition such as Odysseus, Aeneas, Christ, Dante the Voyager, Don Quixote, Candide, Renzo Tramaglino. ${ }^{6}$ In this special issue Patricia Demers adds yet a new perspective by seeing in Collodi's text not so much the quest to be a human child, but the "more inclusive process of becoming human" and establishes parallels with literary genres such as romance epic (Don Quixote), confessional allegory (The Pilgrim's Progress), and science fiction in both literature and film.

In an article from the Italian daily La Repubblica Italo Calvino points out the genetic power of Pinocchio, whose peculiarity is "offrirsi alla perpetua collaborazione del lettore per essere analizzato, chiosato, e smontato rimontato." Calvino's observations are germane to the reflections Giorgio

${ }^{5}$ Sequels and rewritings of the famous story of the puppet are too many to mention. One can just refer to some significant ones in Italy such as Giorgio Manganelli's commentary Pinocchio. Un libro parallelo, Gianni Rodari's La filastrocca di Pinocchio, Luigi Compagnone's La vita nuova di Pinocchio, Giovanni Giraldi's Il figlio di Pinocchio, Umberto Eco's Povero Pinocchio up to the recent theatrical version of Stefano Benni Pinocchia in his collection Teatro 2. For American rewritings and sequels see Thomas Morrisey's chapter 7 in Pinocchio Goes Postmodern. Italian designer Franz Fischneller has created a digital interactive installation called "Virtual Pinocchio" (1999). The technological experience of Pinocchio for the new millennium integrates robotics, animation, digital imagination, interactivity allowing to experience in a ludic setting Pinocchio's life in the twenty-first century. For Pinocchio as cultural icon one can think of the pervasive use of the puppet's pointy nose in the media and the press as symbol of lying. For more on rewritings and the impact of Pinocchio in popular culture see Sandra Beckett's article in this issue.

${ }^{6}$ For bibliographical reference see Perella and Traversetti. For an engaging comparison of Pinocchio and with Odysseus and other heroes, see Pietro Toesca and Wunderlich and Morrisey's chapter 2 in Pinocchio Goes Postmodern. 
Manganelli made a few years earlier in his famous book Pinocchio. Un libro parallelo, the most notable rewriting of Collodi's Pinocchio. Manganelli best captured the essence of Collodi's text when he stated that

Questo mattone interiore del libro, della pagina, include innumere pagine, libri infiniti ... il libro si dilata, è tendenzialmente infinito. Eppure non è mai fittizio. Un grande libro genererà infiniti libri, e così a loro volta questi ultimi: né vi sarà mai l'ultimo. (19)

In Manganelli's words one should stress not only the reference to "grande libro" but also the verb "generare." I would extend Manganelli's formula in order to consider Collodi's Pinocchio not just as a book generating other books, but rather as a text which has generated and continues to generate endless written, theatrical, cinematic, musical, and visual texts.

If Le avventure di Pinocchio engages and fascinates children and even more adults, its hero has become a pervasive presence in contemporary culture. In fact, Pinocchio is so sedimented in our collective unconscious that it has become a cultural icon. ${ }^{7}$ Pinocchio may be more familiar to the general public, particularly in North America, because of Walt Disney's animated picture. ${ }^{8}$ Pinocchio equally engages intellectuals, artists, and the general public, it stimulates reflections, not only on the figure of the boy-puppet, but also on the significance of such uninterrupted popularity of the story and the hero. Sandra L. Beckett expands on this point by giving an exemplary lesson on pinocchiology and demonstrating the persistence of the proteic puppet in various expression of literary and popular culture. From the intertextual literary games by Umberto Eco and Gianni Rodari, to cinematic rewritings by Disney and Benigni, to visual graphic re-readings by illustrators such as Fanelli, Mattotti and Lane Smith, to sequels and adaptations in various languages, to Pinocchio in science-fiction and music, Beckett's essays shows how this icon in Western culture permeates every area of popular culture, thereby confirming the generativity of Collodi's masterpiece.

${ }^{7}$ For better or worse, Pinocchio has become a ubiquitous metaphor in Italian politics, particularly with negative connotations regarding the penchant for lies and deception of people in politics. See for example the cover of magazine L'Espresso (24 Aug. 2000), featuring Roberto Benigni sporting a Pinocchio nose and reading "Pinocchi d'Italia. Il paese delle bugie / dal film alla realtà." Other examples of the use of Pinocchio as liar in American popular culture are in Pinocchio Goes Postmodern (17).

${ }^{8} \mathrm{~A}$ case in point is the unawareness of the younger generations, including most North American university students, that Pinocchio existed before and in a format different from Disney's film. 
The recasting of the story of the puppet in always new artistic, social, political, and media contexts allows for some considerations about the culture and society which produced such variations. ${ }^{9}$ Three essays in this series focus on the impact of the story of Pinocchio on contemporary cultural practices such as cinema and television. Patrizia Bettella's essay examines adaptations by Disney, Comencini, and Benigni, providing some commentary and comparative analysis of three most significant film versions of Collodi's original in the past six decades. Disney's "toy-boy," Comencini's "poor boy," and Benigni's "burattino" are three distinctive versions of the protagonist that reflect different modes of social and cultural practice.

Lise Hogan's and William Anselmi's articles centre on specific issues concerning the reception of Roberto Benigni's Pinocchio in North America. Hogan juxtaposes the flop of Benigni's film in the United States to the enormously successful phenomenon of American Reality TV and recuperates Benigni's message in the face of a general condemnation of the entertainment press. Anselmi attributes more directly the failure of Benigni's Pinocchio at the box office and in the press in the United States to a political strategy intrinsic in Hollywood imperialistic assertion of American culture over others, hence the polarization and antagonism between Benigni's rendering of the boy-puppet in his Pinocchio and the one by Steven Spielberg in the artificial boy of Artificial Intelligence, a film where "humanity is represented as a step in the evolution of mechanical intelligence."

More generally concerned with the minority genre of children's literature during fascism is Maria R. Truglio's article on Annie Vivanti's neglected fairy-tale production. Vivanti's novel for children Sua Altezza!, published in 1923 by Bemporad, the Florentine press which successfully launched Collodi's Pinocchio, is shown to be unique in bringing a subversive message, which upturns the nationalistic bourgeoisie values typically espoused in the fairy-tale genre.

The articles in this special issue of Quaderni d'italianistica rightfully honour and insightfully investigate Carlo Collodi's masterpiece Le avventure di Pinocchio, children's literature, and cultural studies, thereby opening new perspectives and offering original scholarly work in a marginalised and often neglected area of Italian Studies.

\section{University of Alberta}

9In Pinocchio Goes Postmodern Wunderlich and Morrisey for example have shown how Pinocchio's popularity and the distortion of Collodi's book in the United States, through innumerable adaptations, translations and abridgements, illuminate the social and political changes between the First World War and the postmodern present. 


\section{Works Cited}

Barański, Zygmunt G. "Introducing Modern Italian Culture" pp. 1-15 in The Cambridge Companion to Modern Italian Culture, eds. Zygmunt Barański, Rebecca West. Cambridge: Cambridge University Press, 2001.

Benni, Stefano. Teatro 2. Milan: Feltrinelli, 2000.

Bertacchini, Renato. Le "Avventure" ritrovate: Pinocchio e gli scrittori italiani del

Novecento. Pescia: Fondazione Nazionale "Carlo Collodo", 1983.

Calvino, Italo. “Ma Collodi non esiste.” La Repubblica (19 Apr. 1981).

Compagnone, Luigi. La vita nuova di Pinocchio. Florence: Vallecchi, 1966.

Croce, Benedetto. La Letteratura della Nuova Italia. Bari: Laterza, 1956.

Dombroski, Robert, S. "Forward," [sic] Annali d'italianistica 16 (1998): 11-14.

Eco, Umberto. Povero Pinocchio. Verona: Comix, 1995.

Forgacs, David, Lumley Robert. Italian Cultural Studies: An Introduction. Oxford: Oxford University Press, 1996.

Giraldi, Giovanni. Il figlio di Pinocchio. Genoa: Fratelli Frilli, 1978.

Manganelli, Giorgio. Pinocchio. Un libro parallelo. Milan: Adelphi, 2002.

Perella, Nicholas. “An Essay on Pinocchio.” Italica 62.1 (1986): 1-47.

Rodari, Gianni. La filastrocca di Pinocchio. Rome: Editori Riuniti, 1974.

Toesca, Piero. "La filosofia di Pinocchio ovvero l'Odissea di un ragazzo per bene con memoria di burattino" Forum Italicum 31 2(1996): 459-486.

Traversetti, Bruno. Introduzione a Pinocchio. Bari: Laterza, 1993.

Wunderlich, Richard, Morrisey, Thomas. Pinocchio Goes Postmodern: Perils of a Puppet in the United States. New York: Routledge, 2002. 